\title{
Analysis of the Causes of Electrical Accidents Caused by Operating Over-voltage of High Voltage Switchgear
}

\author{
Jungang Zhou, ${ }^{1, a}$, Xueming Fan², Ya Liư ${ }^{1}$, Lei Peng ${ }^{1}$ \\ ${ }^{1}$ Shandong Institute for Product Quality Inspection, Jinan, 250102, China \\ ${ }^{2}$ China Quality Certification Center, Beijing, 100070, China \\ ${ }^{a}$ E-mail: jungang1983@126.com
}

\begin{abstract}
Keywords: high voltage switchgear; operating over-voltage; lightning arrester; transformer; power supply system

Abstract. In this paper, the lightning arrester explosion accident and transformer short-circuit accident in power supply system were analyzed in detail. It was found that the operating over-voltage caused by the frequent operation of the $35 \mathrm{kV}$ high voltage switchgear was the main cause of the accident. It was found that the frequent operation of high voltage switchgear had caused cumulative damage to the insulation property of high voltage power equipment. When the operating over-voltage exceeded the threshold value of insulation performance of power equipment, the insulation breakdown caused accidents. According to the characteristics of the power supply system, the reasonable suggestions were put forward, which was helpful to improve the safety performance of the power supply system.
\end{abstract}

\section{Introduction}

High voltage switchgear is widely used in power supply system. In general, high voltage switchgear doesn't need to operate frequently. In the regular routine maintenance, it needs to close and disconnect operation. In some special applications, it is necessary to carry out frequent close and disconnect operation for high voltage switchgear. High voltage switchgear is generally installed lightning arrester, to limit the over-voltage caused by close and disconnect operation of high voltage switchgear. In order to ensure the safe operation of power supply system.

High voltage switchgear in the power supply system may be subjected to lightning over-voltage and operating over-voltage of two over-voltage damages. According to the measured lightning over-voltage waveform is a kind of non-periodic pulse, according to the domestic and international standards ${ }^{[1]}$ :standard lightning impulse voltage test wave front time is $1.2 \mathrm{us} \pm 30 \%$, half peak time is 50 us $\pm 20 \%$; standard operating over-voltage of the wave front time is $250 \mathrm{us} \pm 30 \%$, half peak time is 2500 us $\pm 60 \%$. The duration of the operating over-voltage is much longer than that of the lightning impulse over-voltage, the shape is more complex, and its shape and duration vary with the specific parameters and length of the line. At present, the international trend is to represent the operating over-voltage with a long pulse of a few hundred milliseconds and a few thousands. Lightning arrester is installed in the high voltage switchgear, which is used to protect electrical equipment from the high transient over-voltage hazard and limit the time. Lighting arrester under normal operating voltage shows a high resistance state, only microampere current through. A low resistance is presented under the action of over-voltage and high current, which limits the residual pressure at both ends of the arrester.

At present, the domestic and foreign related research on this direction is mainly concentrated in the lightning and the operating over-voltage identification ${ }^{[2,3]}$, over-voltage online monitoring ${ }^{[4,5]}$, the impact of operating over-voltage on electrical equipment ${ }^{[6-12]}$ and other direction. For the frequent operation of high voltage switchgear in power supply system, there were less researches on the cumulative damage of the insulation performance of power supply equipment, and there was no relevant report about the accident. The power supply system in the high voltage switchgear frequent operation for the accident caused by the detailed analysis of the causes, and put forward reasonable suggestions to improve in this paper. 


\section{Schematic Diagram of Power Supply System}

The two accidents occurred in the different branch of the same power supply system. The principle of this power supply system is simplified to composed by the $110 \mathrm{kV} / 35 \mathrm{kV}$ transformer, $35 \mathrm{kV}$ high voltage switchgear I, $35 \mathrm{kV}$ high voltage switchgear II, $35 \mathrm{kV} / 400 \mathrm{~V}$ transformer I, low voltage equipment I, $35 \mathrm{kV}$ high voltage switchgear III, $35 \mathrm{kV} / 400 \mathrm{~V}$ transformer II, low voltage switchgear and the low voltage equipment II, as shown in figure 1.

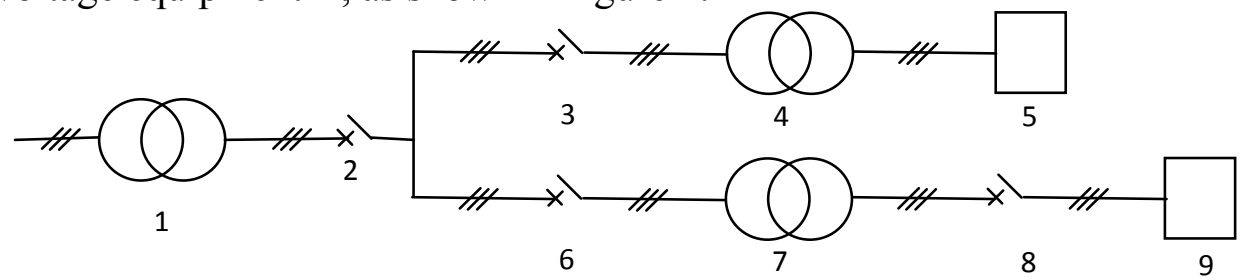

$1.110 \mathrm{kV} / 35 \mathrm{kV}$ transformer, 2. 35kV high voltage switchgear I, 3. 35kV high voltage switchgear II, $4.35 \mathrm{kV} / 400 \mathrm{~V}$ transformer I, 5. low voltage equipment I, 6. 35kV high voltage switchgear III, 7. 35kV/400V transformer II, 8 . low voltage switchgear, 9 . low voltage equipment II

Fig. 1 Schematic diagram of power supply system

The power supply system is composed of the following components. $110 \mathrm{kV}$ substation for the $110 \mathrm{kV} / 35 \mathrm{kV}$ transformer to provide a side power supply, the transformer's two side output voltage is $35 \mathrm{kV} ; 35 \mathrm{kV}$ high voltage switchgear I is the main circuit of the control switchgear; $35 \mathrm{kV}$ high voltage switchgear II and III parallel connected; $35 \mathrm{kV}$ high voltage switchgear II, $35 \mathrm{kV} / 400 \mathrm{~V}$ transformer I and low voltage equipment I compose of power supply branch $1 ; 35 \mathrm{kV}$ high voltage switchgear III, $35 \mathrm{kV} / 400 \mathrm{~V}$ transformer II, low voltage switchgear and low voltage equipment II compose of power supply branch 2 . In the normal power supply system operation, the power supply branch 1 and branch 2 will not work at the same time.

\section{Lightning Arrester Explosion Accident}

The lightning arrester explosion accident occurred in the power supply branch 1 and the power transmission process was as follows. Low voltage power equipment I load, first $35 \mathrm{kV}$ high voltage switchgear II closed, and then $35 \mathrm{kV}$ high voltage switchgear I closed, after the time t, $35 \mathrm{kV}$ high voltage switchgear II disconnected, and then $35 \mathrm{kV}$ high-voltage switchgear I disconnected, the power supply was over.

The lightning arrester explosion occurred in low voltage equipment I no-load commissioning phase, the specific process was as follows.

Accident process: low voltage equipment I no-load, first closed $35 \mathrm{kV}$ high voltage switchgear I, and then closed the $35 \mathrm{kV}$ high voltage switchgear II. As $35 \mathrm{kV}$ high voltage switchgear II closed instantaneous, lightning arrester exploded, relay protection system made the $110 \mathrm{kV} / 35 \mathrm{kV}$ transformer internal circuit breaker in time to disconnect so limited the further expansion of the accident.

The normal installation of high voltage switchgear lightning arrester was in figure 2 , and lightning arrester installed in the $35 \mathrm{kV}$ high voltage switchgear circuit breaker between the into line wire and the ground wire.

The lightning arrester explosion accident scene was in figure 3 , compared to figure 2 could be found in the A phase of the lightning arrester was the most serious damage, followed by the B phase, $\mathrm{C}$ phase damage was relatively light.

The reasons were as follows.

1. According to the provisions 6.2.6.2 of GB3906-2006, high voltage switchgear needs to bear standard lightning impulse test voltage $35 \mathrm{kV}, 1.2 \mathrm{us} / 50 \mathrm{us}$, positive and negative polarity were applied to its rated withstand voltage for 15 consecutive times for each test condition. But there is no requirement for the operation of high voltage switchgear, that is, the performance of the high voltage switchgear has not been considered in the design. The work environment of the accident: high voltage switchgear needs to frequent close and disconnect operation in normal weather, in a 
thunderstorm and other severe weather stopped working. Therefore, the high voltage switchgear in the use of over-voltage is the operating over-voltage, not the lightning over-voltage.

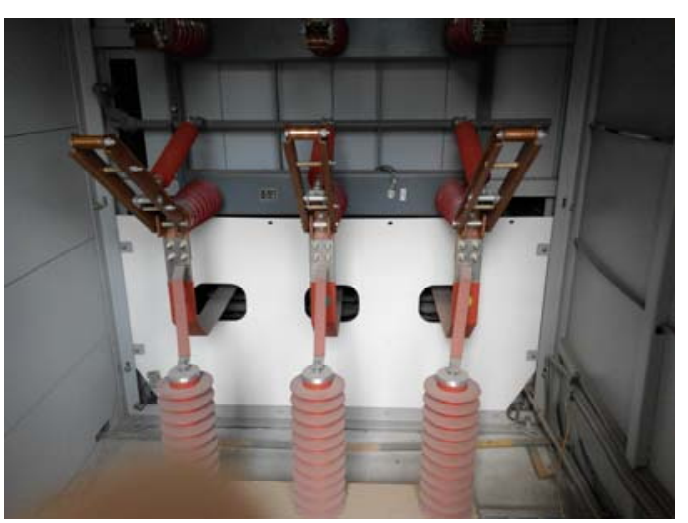

Fig. 2 Normal installation of lightning arrester

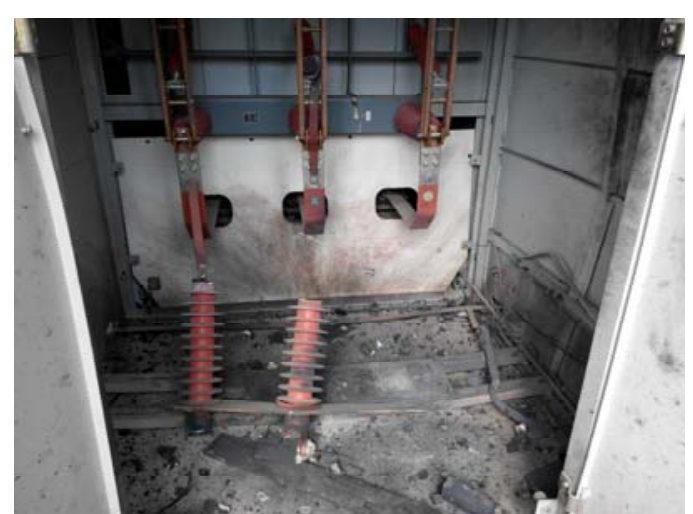

Fig. 3 Accident explosion scene of lightning arrester

2. The amplitude of over-voltage damage not only depends on the waveform, is also associated with the wave-front steepness. The characteristics are different between operating over-voltage and lightning over-voltage. The arrester can't effectively limit the operating over-voltage, but damage the performance of the lightning arrester. The insulation performance of the arrester is decreased under the action of the cumulative effect of the operating over-voltage on the arrester.

3. When the failure of a certain operating over-voltage exceeds the threshold value of the insulation of the arrester, the insulation breakdown of the arrester is caused, and the single phase of the high voltage side is relatively short-circuit, as shown in figure 4.

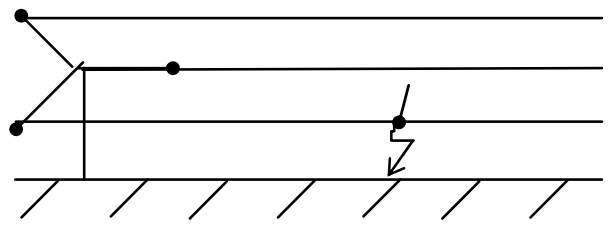

Fig. 4 High voltage side single phase short circuit

Combined with figure 3 and figure 4, the lightning arrester which connected with the high voltage side A was found to be short-circuit. The lightning arrester was difficult to withstand the heat and electrical power caused by short-circuit fault, which caused the explosion of A phase arrester, and damaged the adjacent $\mathrm{B}$ phase and $\mathrm{C}$ phase arrester.

\section{Transformer Short-circuit Accident}

The transformer short-circuit accident occurred in the power supply branch 2 and the power transmission flow was as follows. $35 \mathrm{kV}$ high voltage switchgear III was in closed state for a long time. Low voltage power equipment II no-load. First $35 \mathrm{kV}$ high voltage switchgear I closed, and then the low-voltage switchgear for closure and disconnection operation to control low-voltage power equipment II, the end of the power supply.

The transformer short-circuit accident occurred in the equipment no-load commissioning phase and the specific process was as follows.

Accident process: low voltage equipment II was no-load, $35 \mathrm{kV}$ high voltage switchgear III was in closed state, closed $35 \mathrm{kV}$ high voltage switchgear I. When the $35 \mathrm{kV}$ high voltage switchgear I closed, $110 \mathrm{kV} / 35 \mathrm{kV}$ transformer and $35 \mathrm{kV} / 400 \mathrm{~V}$ transformer II occurred short-circuit accident. The relay protection of the power supply system did not play a role, so that the accident was further expanded, resulted in $110 \mathrm{kV}$ substation main transformer trip and a large area of power cut.

The reasons are as follows.

1. The power supply branch 1 and the branch 2 were in operation and the $35 \mathrm{kV}$ high voltage switchgear was required to be closed and disconnected operation. Each operation of $35 \mathrm{kV}$ high voltage switchgear I would produce the operating over-voltage and $35 \mathrm{kV}$ high voltage switchgear III was in a closed state long time, so directly caused the operation over-voltage shocks to the 
$35 \mathrm{kV} / 400 \mathrm{~V}$ transformer II. Frequent operating over-voltage shocks reduced the insulation performance of $35 \mathrm{kV} / 400 \mathrm{~V}$ transformer.

2. The low voltage side of $35 \mathrm{kV} / 400 \mathrm{~V}$ transformer II was not installed resistance capacity absorption device. Therefore, the long-term accumulation of damage to the insulation performance of $35 \mathrm{kV} / 400 \mathrm{~V}$ transformer II was decreased by operating over voltage.

3. $35 \mathrm{kV} / 400 \mathrm{~V}$ transformer II was the oil immersed transformer and its installation and use for a long time. In routine maintenance process revealed the presence of a small amount of leakage, so led to the transformer insulation performance existed security risks.

4. When a certain operating over-voltage exceeded $35 \mathrm{kV} / 400 \mathrm{~V}$ transformer II insulation performance of the threshold, caused $35 \mathrm{kV} / 400 \mathrm{~V}$ transformer II high voltage side insulation breakdown and phase to phase short-circuit occurred. So the transformer oil inside the transformer blew out.

5 . When the power supply system worked at a time, the $35 \mathrm{kV}$ high voltage switchgear I was required to be closed and disconnected, and the $110 \mathrm{kV} / 35 \mathrm{kV}$ transformer had the operating overvoltage shock. The transformer insulation performance damage long-term accumulation by operating over-voltage, mad the insulation performance of the transformer decreased.

$6.35 \mathrm{kV} / 400 \mathrm{~V}$ transformer II high voltage side insulation broken down through the line reacting on the $110 \mathrm{kV} / 35 \mathrm{kV}$ transformer, made the $110 \mathrm{kV} / 35 \mathrm{kV}$ transformer high voltage side and low voltage side insulation broken down at the same time. The high voltage side and low voltage side occurred phase to phase short-circuit. After the accident, the insulation resistance test found that the transformer's high voltage side, low voltage side, to ground mutual insulation resistance about $5 \mathrm{M} \Omega$.

7. The accident occurred in moment for $110 \mathrm{kV} / 35 \mathrm{kV}$ transformer and $35 \mathrm{kV} / 400 \mathrm{~V}$ transformer II, resulted in the power system relay protection failed to play a protective role and led directly to the primary power system relay protection played a role, so resulted in a large area of power cut.

\section{Suggestions on Improvement of Power Supply System}

The operation over-voltage occurs in switching no-load line, switching no-load transformer and reactor, all kinds of fault. The operation status of the system changes suddenly, which leads to the conversion of electromagnetic energy between the inductive and capacitive elements in the system, so generates operating over-voltage. The amplitude and duration of the operation are related to the structure parameters of the power grid, the performance of the circuit breaker, the connection of the system, the operation type and so on.

Through the analysis of the above two accidents, suggestions were put forward for improvement of the power supply system in this paper.

1. Lightning arrester type selects zinc oxide lightning arrester, and effectively monitor whether the lightning arrester is in a reasonable range of use.

2. The resistance capacitance absorbing device is added in circuit breaker inlet port of the $35 \mathrm{kV}$ high voltage switchgear so limits the peak value of operating over-voltage and absorbs the energy of over-voltage. The connection mode of resistance capacitance absorbing device is $\Delta$ to avoid the occurrence of high voltage side grounding short circuit.

3. The circuit breaker in high voltage switchgear uses parallel resistance circuit breaker, to reduce the operation over-voltage between closure and disconnection operation for high voltage switchgear.

4. The resistance capacitance absorbing device is added in the low voltage side of the transformer. The low voltage side limits operating over-voltage effect on the power supply system.

\section{Conclusions}

The lightning arrester explosion accident and transformer short-circuit accident were analyzed in this paper, it was pointed out that the frequency of operation of high voltage switchgear in electric equipment insulation performance caused by cumulative damage, which was the fundamental cause 
of the accident. According to the power supply system, put forward some improvement suggestions to improve the safety performance of the power system.

The frequent operation of high voltage switchgear generated operating over-voltage, which impacting on electrical equipment was analyzed in this paper. In order to solve the problem, how to carry out the quantitative analysis, set up the mathematical model, design the corresponding equipment is the focus of the next step.

\section{References}

[1]. IEC60060-1-2010 High-voltage test techniques-Part 1: General definitions and test requirements. Switzerland

[2]. Yang Yong, Li Licheng, Du Lin, et al. Power System Technology, 2012,36(8):31-37(In Chinese).

[3]. Du lin, Li Xin, Sima Wenxia, et al. Electric Power Automation Equipment, 2012,32(8):35-40(In Chinese).

[4]. Du Lin, Li Lin, Sima Wenxia, et al. High Voltage Engineering, 2012,38(3):535-543(In Chinese).

[5]. Yang Q, Wang J, Sima W, et al. Energies, 2011, 4(9):1410-1427

[6]. Deng Xu, Wang Dongju, Shen Yang, et al. Electric Power Automation Equipment, 2014, 34(1):141-147(In Chinese).

[7]. He Ziming, Chen Weijiang, Chen Xiujuan, et al. High Voltage Engineering, 2012, 38(4):838-846(In Chinese).

[8]. Chen Xiujuan, Chen Weijiang, Shen Haibin, et al. High Voltage Engineering, 2007, 33(11):1-5(In Chinese).

[9]. Sima Wenxia, Lu Chen, Yang Qing, et al. High Voltage Apparatus, 2015, 51(9):1-8 (In Chinese).

[10]. BALAJI S P, SHEEMA I, KRITHIKA G, et al. IEEE transactions on Dielectrics and Electrical Insulation, 2011, 18(6):2069-2073.

[11]. SHIGEMITSU O. IEEE Transactions on Dielectrics and Electrical Insulation, 2006, 13(1):436-444.

[12]. BHOOMAIAH A, MUKHERJI S, GUPTA S C, et al. IEEE Report Conference on Electrical Insulation \&Dielectric Phenomenon, 2005,206-209. 